\title{
Russian cultural-historical consciousness in Early Slavophile philosophy
}

Marina Shirokova

Altai State University, 656049, 61a Lenina prospect, Barnaul, Russia

\begin{abstract}
In this article, the author describes the concept of "culturalhistorical consciousness" as substantial matter of any nation or any period in the cultural and historical development. Russian cultural-historical consciousness is considered to be the appreciation of Russian culture by its people. It is the acknowledgment of its destination and values in correlation with other cultures and the world in general. As for correlation of such concepts as "cultural-historical consciousness" and "national consciousness", the national or ethnical principle represents one of the cultural-historical aspects. In the author's opinion, slavophiles conceived Russian philosophy as one that truly reflects the national consciousness. They were pioneers who managed to put together the logical-conceptual tools of European science and the mindset heavily influenced by the orthodox culture, as well as included it in our national language and consciousness.
\end{abstract}

\section{Introduction}

Nowadays, the interest towards the heritage of slavophiles in contemporary philosophy is growing. It is due to the fact that they were the first of all in the educated Russian society who made a great attempt to theoretically comprehend the country and themselves. They tried to see into their distinctiveness and state their place in the historical process among other nations. The Russian cultural-historical consciousness became a self-consciousness, a selfreflection that grasped not only the subject itself (which is Russia as a civilization and a culture), but the very way of thinking and its peculiarities.

\section{Understanding the nation's consciousness in Slavophile philosophy}

The Russian cultural-historical consciousness is the appreciation of Russian culture by its people. It is the acknowledgment of its destination and values in correlation with other cultures and the world in general. It should be noted that a cultural-historical consciousness could be regarded as a substantial matter of any nation's cultural and historical development in any historical period. In other words, it is not only what the people think of themselves and the world, but it is also a complex of all the essential aims and purposes of their cultural, historical, political and religious life, which define the way of being. This concept traces its origin to N. Y. Danilevsky's "historical-cultural type" or Oswald Spengler's "phenomena of culture". On that basis, the matter of cultural-historical consciousness can only be comprehended beyond the period of time, the substantial foundation of which it used to be. 
That comprehension may become a premise for changes in a modern approach to culturalhistorical development. For this reason, the Russian consciousness, according to the slavophile perspective, truly uncovers itself now from a point of new historical experience. That problem becomes hermeneutical. In words of Hans-Georg Gadamer, it involves understanding the author better than they understood themselves. The idea of hermeneutic circle suits for this purpose. It means that the whole is understood by reference to an individual, and that individual is understood by reference to the whole. This is the way in which the slavophiles' idea may be seen - the concept of society through the concept of a human being, and vice versa. In the same way the comprehension of slavophile theology could be achieved through its philosophy and vice versa. Otherwise, the interaction with the text, traditions and the process of cognition would be shut down.

Considering the correlation of concepts "cultural-historical consciousness" and "national consciousness", it should be stated that the national or ethnical principle represents one of the cultural-historical aspects. Danilevsky considered it one of the basics of the culturalhistorical type. However, his methodology can't be used at it is while studying the ideas of early slavophilia. It is due to the fact that Danilevsky is primarily a biologist and a positivist. Rather than slavophiles, he believed that the ethnical aspect had much more value. But it is important that not only the cultural-historical type theory does not renounce the idea of shared history of the humankind (maybe even against Danilevsky's words) but implies it [1, p. 60]. Self-consciousness is the core of consciousness and a factor of its unity, making it focus on itself as a subject. This is why, nation's self-consciousness is a part of its consciousness, although it may be manifested in different ways and may not always reach the higher point of philosophical self-reflection. That's the way in which slavophiles conceived Russian philosophy as one of national consciousness. The subject of Russian philosophy is Russia itself. It comprises the so called Russian idea, which is a complex of interpretations about national and global destinations and cultures. Russian philosophizing had been specifically developing within the slavophile and westernism discourses.

Some modern scholars think that the opposition of slavophiles and westernizers should be stopped. It brings back the Ivanov-Razumnik's thesis from a hundred years ago, which is about the end of the "great split of the Russian intelligence". N. I. Tsimbayev's scientific interest has lately been focused on the Russian philosophy of the XIX century and its role in the formation of national consciousness. He thinks that the constant opposition of westernism and slavophilia views is damaging to this consciousness. The scholar traces the same origin of both in the Russian "educational europeism" [2]. The advisability of marginalization of the long Russian westernism and "anti-westernism" (avoiding the word "slavophile") discourse is mentioned in O.Y. Malinova's works. However, the author admits that "the factors that determine the formation of such discourse still continue to exist". Therefore, it is going to be even "longer" while shaping the future structure of the Russian politicalideological spectrum [3]. V .I. Kholodny goes even further, considering the antithesis of slavophiles and westernizers as a specific form of the "global contradictory correlation between spontaneously forming self-image and civilizing evolution of society" in certain historical and national conditions. That is between the spiritual and material sides of being, between cultures and civilizations. This theme is primary in any philosophical analysis. And it is mostly those people of culture who tend to self-reflect on the substantial problems "through the prism of both national and personal peculiarity"; they are regarded as philosophers $[4$, pp. 93, 96]. Sharing this point of view, it should be added that the end of discourse of slavophiles and westernizers would mean the end of Russian philosophizing as much as of an active intellectual practice at all.

F. I. Girenok states, "As the Greeks spoke, their words revealed the essence of the world. As we speak, there's not a thing revealed but only Russia" [5, p. 33]. On the one hand, it is a reproach of Russian philosophy. But on the other, it is a certain advantage. There is a reason 
why F. M. Dostoyevsky said that the main feature of Russian consciousness was the universal empathy. This is why, it is able to feel the other nations' spirit deeply and see them as significant Others. They are important partners in dialog. The universal human values are being apprehended through the national values, not being obscured by them.

According to Pavel Florensky said, "As a symbol, slavophilia is lasting, because it is a symbolic manifestation of the Russian self-consciousness". "There is hardly an exaggeration in these words", as pointed out by S.S. Khoruzhiy in "Modern problems of orthodox world outlook". He continues, "The problem of manifestation of the Russian consciousness was the main purpose of slavophilia since the very birth of it". [6, p. 2] It is clear that the Russian consciousness did not appear out of nowhere. It has existed long before slavophilia, but it was rather vague, blended in life of the people. "Society, like a human being, becomes selfaware not by the means of logic. Its consciousness is the life itself; it lies in the unity of traditions, in the identity of moral or mental intentions, in continuous exchange of thoughts, in all the incessant excitement that the nation and its history is based on" [7, p. 96]. These are the words of A. S. Khomyakov, one of the forefathers of slavophilia. In his turn, F. I. Girenok said, "It seems to me that Khomyakov likes odd definitions... Could it be that life is consciousness? Consciousness is something that thinks and ponders... And something living just lives" [5, p. 60]. Khomyakov was certain that the nation's consciousness is "inaccessible both to the foreigner and those members of society that are withdrawn from it, willing or unwilling" [7, p. 97]. Therefore, it is inaccessible to the upper class, which is of the European enlightenment type, but, as a consequence, inexpressible to the people, as they do "live", but do not "ponder". "In the upper class, the knowledge had been manifested, but it was rather detached from life; and in the lower class, there was life that had never risen to the level of consciousness" [7, p. 99]. F. I. Girenok considered such non-conscious life a "literality" with something unstated in it. Slavophile authors saw their destination in bringing the Russian life to the level of consciousness and expressed "something that lives" in rational way. To achieve this, the educated classes should leave the imitativeness behind. As Khomyakov said, they should stop repeating "the acquired thoughts in acquired languages" and start speaking Russian for Russia. "To be an obedient and artistic instrument of our thoughts, the language should be not only a part of our knowledge, but a part of our lives and ourselves" [7, p. 97]. It may be right that slavophiles and Khomyakov in particular bring "the experience of pronouncing the literal" into Russian spirituality. "To pronounce the literal means to let something be expressed through yourself" [5, p. 47]. It is time for language of the nation to naturally absorb "metaphysical concepts". "Scholarship, politics and philosophy haven't been expressed in Russian yet. We have no metaphysical language at all" [8, p. 18], as written by A. S. Pushkin in 1824. It is obvious that he realized the difficulty of that problem. The educated class had to work on the original Russian "scholarship, politics and philosophy" and create proper Russian literary language at the same time. In the article "The reasons of delayed development of our philology," Pushkin thinks that the main reason of that is the wide usage of French and the neglect of Russian. "Our writers used to complain about that, but who's to blame if not themselves". It is truly hard to deliberate in mother tongue when it is so rough that "even in casual letters we have to create" suitable turns of phrase "to express the simplest notions". Thus, "our indolence is easier to be put into other language that is already equipped for use" [8, p. 18]. The slavophiles were pioneers who managed to put together the logical-conceptual tools of the European science and the orthodox culture mindset and included it in our language and consciousness.

\section{Conclusion}

The Slavophilia philosophy reflects not only the already existing archetypes and values of the folklife culture, but also the features of a new emerging high culture. And slavophiles 
themselves were a part of it. It is recognized by now that this high culture made a global impact that is comparable to the Ancient Greece and Roman Empire. Obviously, narrowing the concept of culture to consciousness does not always make sense. But in this case, it is acceptable to agree with V. S. Nepomnyashchiy, a well-respected philosopher and theorist of literature, an author of works on the Russian world view who studied the legacy of A. S. Pushkin. Describing the Russian culture of artistic minority, he writes, "It is known that the culture is the consciousness of a nation. It is important to mention what culture implies. Some people believe that it is concluded by the sum of works of art made out of any material. But you can't pack a culture in a suitcase. That mainstream point of view is shallow. That personalized authorial culture is highly important, but it is only a part of the national culture with its lifestyle and psyche, its ideals and traditions, its morals and human relations... All of that is a base of personal culture. In other words, authorial culture is the intermediated nation's self-consciousness" [9, p. 216]. Thus, the slavophile philosophy is the Russian consciousness as well.

One of the modern authors that made an impact into developing the problem of "Russian idea" is A. A. Korolkov. He writes that the slavophiles were the initiators of "the first definite reflection of the peculiarities of Russian enlightenment that defined the features of Russian culture, philosophy, art and literature" [10, p. 638]. He emphasizes one of those features in the slavophile philosophy, "I. V. Kireyevsky was the first person to name Russian philosophy a spiritual philosophy. It is aimed at comprehension of human and nation spirituality and it is distant from the western one" [10, p. 632]. It has to be noted that some people did not admit that slavophiles managed to create an authentic philosophy that was different to the Western one. It is known that V. S. Solovyov was quite skeptical about the distinctive character of the Russian philosophy in the XIX century. He wanted to prove that all the native authorsphilosophers, including slavophiles, were actually Europeans in terms of their scholarly endeavor. He thought that "all the philosophy in their words was not Russian, and what was Russian did not look like philosophy or like anything at all" [11, p. 345]. And yet, most scholars do not agree with this. As it was noted, using the conceptual construct and methods of Western philosophy in an inventive way, the slavophiles were able to set a challenge of remembering the roots of their culture. They set out to trace its origin and to find out that culture must learn from its nation and give something back in return. Quoting a contemporary philosopher from St. Petersburg, who believes that the slavophiles were the pioneers of Russian philosophy, professor A. L. Kazin, "The Russian philosophy is something that the national culture can say about the world and people by concepts [12, p. 572]".

In this way, the founders of slavophilia lived and worked in time when a new national culture was forming, and it had to be manifested with an original philosophy.

\section{References}

1. A. I. Zimin, Sotsiologicheskiye issledovaniya, 2 (1996)

2. N. I. Tsimbayev, Ocherki Istorii Russkoy Kultury XIX veka, 4 (2003)

3. O. Y. Malinova, The mirror labyrinth: the "long discourse" of Russian Westernism / antiWesternism and the problems of forming a national identity (http://ashpi.asu.ru/talks/ths_2007/ths01/mlnva.html, 2007)

4. V. I. Kholodny, Khomyakov and modernity: The origin and perspective of conciliar phenomenology (Moscow, 2004)

5. F. I. Girenok, Pathology of the Russian mind: literature cartography (Moscow, 1998)

6. S. S. Khoruzhiy, Contemporary problems of the Orthodox worldview (Moscow, 2002)

7. A. S. Khomyakov, About the old and the new: articles and essays (Moscow, 1988)

8. A. S. Pushkin, Collected works in 10 volumes (Vol. 7) (Moscow, 1958) 
9. V. S. Nepomnyashchiy, Pushkin: izbrannyye raboty 1960-kh-1990-kh gg. (Vol 1: poeziya i sudba) (Moscow, 2001)

10. A. A. Korolkov, Collection of articles on the materials of the international scientific conference, held on April 14-17, 2004 in Moscow in the Literary Institute named after A.M. Gorky (Moscow, 2007)

11. V. S. Solovyev, Essays in 2 volumes (Vol. 1) (Moscow, 1988)

12. A. L. Kazin, Collection of articles on the materials of the international scientific conference, held on April 14-17, 2004 in Moscow in the Literary Institute named after A.M. Gorky (Moscow, 2007) 